\title{
Europe Out of Europe: The View from the Other Side of the World: The case of Matt Wellwood
}

\author{
Markieta Domecka
}

\section{Introduction}

This chapter focuses on the life history of 39-year-old Matt Wellwood, originally from New Zealand and now living for a number of years in London and commuting on a regular basis to Germany, where his wife and daughter live. Matt's history is interesting as it shows the perspective of a man with European roots (his father was born in England), born and brought up outside the continent, who decided later on to move to Europe. ${ }^{1}$ Following his biographical development, special attention will be given to the reconstruction of Europeanness (in particular, Englishness) outside of Europe, the hierarchies and distinctions involved and the cultural hybrids which are the outcome of this process. Subsequently, the meaning of Europe for biographical development and identity construction will be reflected upon, together with the process of developing roots and homebuilding.

\section{Growing up in 'a very European city'}

In the preamble to his narrative Matt tells a humorous story about himself, a fiveyear-old boy, watching a digital radio clock and waiting to see 5:55 displayed there. The story is given a self-distancing introduction: 'disappointingly the first thing I remember is quite late in life' and is followed by an ironic comment: 'I probably sat there for 20 minutes so I wouldn't miss this striking event'. Selfdistancing and irony form the general mode of his story telling. Subsequently, Matt explains that the rest would be fragmentary 'child memories', which 'the more you play them, the less certain you are if you're actually remembering the original or remembering the process of

\footnotetext{
${ }^{1}$ This case is also interesting as it overlaps with several different sensitised groups we constructed at the beginning of the project. Coming from New Zealand, Matt belongs to the 'outside Europe' category; working in London he is a 'transnational worker', and having a German partner he can be also ascribed to the group of 'cross-cultural intimate relationships'. Overlap between sensitised groups was a common occurrence.
} 
remembering them'. After this reflection, with some hesitation, he opens up his narrative: '-ehm-, yeah, I was born in, in Auckland in New Zealand', which in fact is a story of the place, with its differences between the North and the South; the ambiguities created by the New Zealand Company, which Matt describes as an 'English colonising company'; a desire to 'reconstruct a kind of idealised English society' and the lack of self confidence of 'a small country that's uncertain of its position in the world'. Matt adds that only after the Second World War 'people had a confidence that there was actually such a thing as a New Zealand identity. As opposed to it simply being kind of very remote county of England.' This narrative of place serves Matt as an explanation for why the location where he was growing up was 'still thought of as a very European city'. Being a reflective person, as the whole narrative demonstrates, Matt does not stop here, but continues explaining what he means by 'European', including the ambiguities inherent in the term:

Now by European I mean racially Caucasian. -ehm- what in New Zealand we call Pakeha, which, which in itself is an odd -ehm- or disputed word, whether it simply means non-Maori ... actually there's a lot argument about our, is there such a thing as a pure blooded Maori anymore? It's certainly true that there must be very few. - ehm- and the Pakeha also have Maori blood.

Matt realises that blood alone is a vague criterion for the construction of collective identities and that it has been manipulated, both nowadays and in the past. Discussing the question of national identity he says that 'Auckland was a Pakeha city predominantly', though rather welcoming towards Maoris and Polynesians as a labour force. Matt makes a comparison here to the situation in Germany, where 'large numbers of Turks were imported'. Germany as a meaningful point of reference will appear again and again throughout the whole narrative. This is not surprising, as Matt's wife is German and the couple has plans to settle down in that country. Discussing different ethnic groups Matt sums up saying: "when I was first aware of it, it was very much a Europe, well European led state racially not ehm- you know, not necessarily culturally'.

\section{Distinctions of transplanted Englishness}

Matt's father is English, which is described immediately as 'convenient' as it gives Matt an EU passport, sparing him lots of visa related problems. He comes from an upper-middle class family of doctors, whose attempts to transfer their elitist distinctions into New Zealand's egalitarian society caused a series of clashes, which Matt tells as humorous anecdotes:

My grandmother certainly didn't like New Zealand at all and in one, one spectacular piece of folly -eh- she put a sign on the front door of the house that tradesmen -eh- please use rear entrance. 
Matt's father migrated from England to New Zealand when he was 15 years old. In fact, he was forced to follow his parents despite his disapproval of the decision to migrate. At university he met 'a local girl', coming from a small town, and decided to marry her, which according to Matt, was an act of rebellion. In sum, neither family was happy with the marriage as they deprecated each other for being 'provincial' on the one hand, and 'snobbish' on the other.

Not having much money at their disposal, Matt's parents bought 'a fairly small slum house' but still in 'a good suburb' of Auckland. 'Good' in this context meant 'where the people who wanted to feel that they were still somewhat English tended to live', where the houses were built ostentatiously in the English style and 'where the local shops had the kind of furnishing that you'd see in England'. This conspicuous Englishness was stigmatising for Matt, who would be called Pom at school. Thinking about English architecture in the completely diverse climate of New Zealand leads Matt to the conclusion that 'one way to show that you have money and power is to set your face against common sense'. And in this sense, his family house 'would be trying to be very English despite this actually giving you a worse quality of life'.

The reflection on the impact of the English arriving in New Zealand inevitably leads Matt to the question of colonialism. In the background construction cutting his main story line he discusses the colonial street names and the ambiguities of colonial wars, again in contrast to the 'a lot easier to commemorate' European wars. Closing the background construction Matt says: 'So -ehm- I appreciate I'm rambling', and goes back to the previous argumentative segment dealing with his father and the ambiguities of Englishness in the context of post-war New Zealand.

My father was quite, he's always been quite, I think quite torn by it in, in a way eh- because he -eh- just from his accent and his upbringing he is actually very English. But he made a conscious decision to repudiate England. -eh- as part of repudiation his parents, he became, you couldn't say active, not in the creative sense, but he became close to the artistic community in New Zealand ... so that, you know, that was one side of his was being methodically non-English. And yet, you know, he was living in [the name of city district] and he sounds like a Pom. So this, you know, this marked him as an outsider. ... So, I think through, you know, really through long after I was born this, this was a ... a theme in life -ehmand something I was generally aware of, just this, this kind of partial, not really a contempt but dis, dislike. He decided to live in this community and he wanted to be a New Zealander, a Pakeha, but at the same time (but?) dismay and dislike for what I did.

As well as the passage cited previously many other argumentative segments suggest that Matt is confronted with a difficult biographical problem. $\mathrm{He}$ 
needs to work out his own stance towards the cherished, on the one hand, and on the other, contested Englishness of his family. He also needs to deal with his Pakeha identity, being perceived as a descendant of European colonisers and at the same time being very critical towards colonialism and postcolonialism. The great length and detail of Matt's account of the complexities of his background tell how important these issues are for him. Thanks to his decision to move to London, Matt is able to work out a more balanced and down-to-earth view on England and Englishness, distancing himself both from the distinctions of transplanted Englishness typical of his paternal grandparents and from the apparent repudiation of Englishness practiced by his father.

\section{Postcolonial, English, European}

Only after describing the country and the city, and then telling his family history, which took around 40 minutes of his narrative and which resembled a preparation of the setting for his own story, Matt realises:

yeah, so -ehm- I've told you remarkably little about myself at this point. Except possibly by inference of what I'm dancing around. -ehm- so some blunt boring facts, and so I was born in 1970 -eh- I've got a sister three years older than me. -ehm- we, as I say, we, we grew up with this kind of, this cultural background of being ... definitely postcolonial you could say, not, but still not particularly Pacific Island, you know, it's all very, very English European really.

The complexities of Matt's background, described as postcolonial, English and European is in fact a red thread of his narrative. England, Europe and New Zealand are not only geographical and cultural reference points but also meaningful biographical poles critically assessed and constantly compared. They are also different but parallel social worlds Matt belongs to, and his attempt to participate in all of them simultaneously requires a great deal of biographical work.

Matt describes his childhood as happy and quiet in 'a relatively small and provincial place'; his home full of books; the happy marriage of his parents; being 'left wing and socially self-conscious'; his mother being a school teacher and having long holidays. After leaving school, Matt went to university, which was a matter of habitus in a sense that it was 'almost just an automatic thing'. There is also some argumentation interwoven in the childhood story. England appears here as a reference point as Matt contrasts the safety of his home place with the media picture of contemporary highly dangerous Britain.

The story of a happy and innocent childhood, free from consumerism and external threats, becomes then sharply contrasted by some trajectory experience. In a background construction nested in the main narrative, 
Matt has the need to tell the story of his mother's illness. Finishing the description of his school years, Matt expresses some hesitation and makes a short pause preparing himself to tell about his painful experiences:

-ehm- yeah, /so/ -ehm- what to say? So ... so my mother died when I was 20 -ehm- which curiously was already a blessing, not to the death, -eh- but she actually originally come down with breast cancer when I was five. So, she was lucky enough to have a very, you know, one of these intelligent doctors who -ehm- virtually follows the literature -ehm- and he got her onto tamoxifen when that was a very brand new treatment. Very, you know, still pretty much experimental. -ehm- so that got us 15 more years.

Matt tells about the death of his mother in just a few words, avoiding a dramatic tone. He mentions that afterwards he behaved like 'a selfish little bastard' racing on his motorbike and finally having a crash.

\section{Europe and the open question of home}

After describing his passion for motorbikes, Matt mentions briefly a girl he lived with for a few years and then starts a story of his first travel to Europe. He was 24 years old when he came to visit his best friend who was doing part of his Ph.D. in Germany.

So it was a sort of golden opportunity to, you know, to meet up. Because, you know, we had a car and so on and, you know, we spent some months eh- travelling around in Europe. And so that was, that was my first encounter with Europe. So we finally get to the point that you actually $(($ laughing until +$))$ are interested in $((+))$.

Cruising European cities and art galleries was in fact 'the big overseas experience', which, as Matt explains, has a strong tradition in New Zealand. The European journey continued as together with his friend Matt decided to work for a few months in England. For the next few years he was in a constant pendulum movement between New Zealand and England, working in these two locations for the same IT company. The final decision to move to Europe was taken as a result of Matt's relationship with a German girl. The couple maintained a long-distance relationship for several years. Trying to reduce the distance, Matt's partner decided to look for a job in New Zealand. Unfortunately, the terms she was offered were much worse than those at her previous job in Germany. The couple was forced to search for another solution, which for Matt was a biographical turning point.

So then that really made it apparent that we'd be, you know, if we were hoping to be living together that would be me going to Europe. 
England seemed to be the best place to work for both of them, however, they were soon confronted with the wall of 'European bureaucratic incompatibility' as Matt's wife, in spite of being offered a job in a big English institution, had tremendous problems getting her qualifications recognised.

What she had was the equivalent of a Masters and in fact you could say rather more thorough than an English Masters degree, it certainly takes rather more time. However the name for it is a diploma and of course in the English system a diploma is something that, that you give a kid who's not bright enough to go to university.

In such a situation, Matt's wife decided to move to Germany to do her Ph.D. there. Matt stayed in London and for the last six years he has been commuting between London and the eastern part of Germany. Narrating about the decision to have a baby sooner rather than later Matt admits his and his partner's age was an important factor. Reflection on the age difference between parents and children then triggers an argumentative passage where Matt feels he has to explain what he means by family and home.

Indeed actually that's exactly what happened in my family, sorry, my New Zealand family -eh- because, now here's a European identity point for you, you know, I, I have trouble defining words like family and home because if I'm lazy I'm just going to fall back upon, you know, my origins. So, home would mean New Zealand and family would mean, you know, my, my, you know, biological family. -ehm- but I'm quite clear that London isn't home. -ehm- London is the place that I make money in. You know, it's where I work. I commute as much as I can to Germany and I work from home there -ehm- and so that's home with a capital $\mathrm{H}$, which the, the wry point there being that, that New Zealanders of the [name of the Auckland city quarter] sort, used to refer to England as home with a capital H. Because it was seen as, you know, that was, even if you'd never been there, you weren't born there, even if you were two generations removed, that's still really home sort of culturally, spiritually. -ehm- so yeah, so in a kind of somewhat joking way but I, you know, I take Germany to be home in that way but it is, but it is - it is also a deliberate point to make sure that I remember where my priorities are.

The question of where Matt and his family are going to live long term is still open and he admits it creates some tensions. The three likely places are Germany, England and New Zealand. As opposed to a spiritual attachment to England kept up in the Auckland middle-class quarter where Matt grew up, his present connection to Germany is very practical. He understands the emotional attachment of his partner, at the same time doing contrastive comparisons with the two other options (regarding educational systems, job 
markets and pension schemes), and he calculates that Germany would be the best place to settle down. He is also aware that, living for many years away from New Zealand, he is losing touch with the practicalities of everyday life there. At the same time he seems to be fond of his rose tinted spectacles, remembering it first of all as a place of his happy childhood and youth.

The concept of home seems to be deterritorialised to some degree here. Germany is a potential and rationally grounded place to settle down; New Zealand is a 'kind of nostalgic dream'. However, a small town close to London may become a temporary home as Matt and his wife, Sara, are buying a house there. It is a turning point in his family life, which, as this argumentative passage demonstrates, needs to be reflected upon and biographically worked through.

You know, you know, so right now with Sara not working and I've got a quite good job with [name of multinational company based in London] ehm- it makes sense for, you know, for us to remain based in England. And indeed -ehm- we're buying a house in [name of town] because that's, you know, having stomped around it seems like a, a, a good compromise of all of, you know, all the different criteria that we feel are important. -ehincluding not being in London. -ehm- the great when? -ehm-/so/ you know, so we'll be back together again as a family because obviously for a small child, you know the commuting lifestyle is, you know, far worse. It means I'm not supporting Sara as much as I, you know, would like to be because, you know, I can only do that when I'm there. -ehm- but also I think for our daughter, you know, it's a much more disrupted, you know. Sometimes, you know, she's got her daddy there and sometimes not in this kind of random way. So -ehm- so, you know, we're ending that. -ehm- but, yeah, longer term the question of where we live and, and where we feel happy, I mean I do wonder if I may have become something of a kind of a ehm- not exactly a Flying Dutchman, you know, but -ehm- not really even an outsider but just somewhat rootless you could say. ... So it leaves me very uncertain of what to do, you know, what, what we will be doing in the, in the future and what kind of happiness it would make for us.

Due to Matt's background, Europe is not culturally strange. He does not, however, think about his moving to Europe in Simmelian terms of 'home-coming'. He distances himself from England as the spiritual homeland cherished by his grandparents. His attitude is much more pragmatic. Taking his decision to move or to stay he considers all the pros and cons, comparing different locations in Europe and outside Europe. And it seems that his decision of where to build a home is more of a practical than a sentimental nature. Matt recognises the European opportunity structure open to him thanks to his European passport. He is not a migrant in the traditional sense, escaping poverty or a dead-end life situation in his country of origin, but 
a transnational man in a new sense, moving freely through space in search of the best place to live. This freedom of choice is an achievement but at the same time a burden. There are plenty of options available but there are also lots of doubts about the choices made. Decision making in such a context is a difficult biographical task requiring reflection and self-knowledge. There is also a risk that Matt, like his father before, will become a marginal man, an outsider, feeling out of place in whatever location he chooses as his potential home. It is also possible that home for him will become completely deterritorialised, depending on emotional bonds with his family and meaningful relationships with other people, rather than any specific geographical point in space.

\section{Privileged Europeanness}

Living in Europe Matt feels privileged not only by his EU passport but also by his skin colour. He is aware that Europe is not colour blind and the fact that he is white is an advantage. He recalls some situations, in which being white felt like being safe.

Being Pakeha helped a lot because I, you know, it's not that I particularly look like a local ... But I don't, but I don't, you know, why am I dancing round the point? I'm not black and I'm not Asian so for an East German collapsed city like, not that it's collapsed dramatically but, you know [name of the city] has got its -eh-its share of, you know, of skinhead types.

Matt declares he could imagine himself living in Germany but rather the Western part of the country, where he 'does not feel like an alien'. At the same time he admits there is a part of him that wants to go back to New Zealand, which he thinks may be 'just nostalgia'. In the pre-coda argumentation, the question of language also appears. Matt feels sorry he has never learnt good German as that would enable him to function better in Germany. He also hopes this fact does not say anything about the seriousness of his relationship with his wife. Then, he also considers another option, which is moving to a country in the north of Europe where his company's 'parent' is based and where he could easily function speaking English only. This reflection is followed by a short pause and the first part of the coda: '-ehm- ... /-mmm-/ ... Yeah, I could ramble on endlessly but that's pretty much brought us to the current day I think.'

Then Matt decides to 'add one thing' and starts explaining how much thought he and his wife put into choosing the names for their daughter. It had to be something easily pronounceable for English speakers and preferably without umlauts. This leads Matt to tell the story of his wife who experienced many problems with English administration just because her 
surname contained an umlaut. Summing up Matt states that they did not want to give their daughter a name that would stand out 'for just ease of integration'. In other words, they decided on 'a boring European name and European even including England in that definition'.

Approaching the coda once again Matt states that he has 'a very ambivalent relationship with England as a place to live'. And he continues: 'they're producing a society that I don't wish to live in'. Then excusing himself for 'using so much of the tape' Matt finishes his narrative.

\section{A thrill of recognition}

Like many of our interviewees coming from other continents, Matt has a feeling of familiarity when coming to Europe for the first time. This familiarity is not limited only to England, the cultural context he knows best, but applies across western Europe. He also observes that 'further down there will be a close cultural resonance' with the country where he was born and brought up. Matt admits that the first time he came to England he experienced a 'thrill of recognition' of the London landmarks. In Germany, besides being greatly impressed by super fast trains, Matt also thought German 'culture isn't that different to English culture, on the surface anyway. You know, the way people look, the way they behave ... even with bad German you can still look over somebody's shoulder and read the newspaper'.

What does it mean to be European? For Matt, it means to 'get a lot more irrationally pointlessly upset with local problems'. He gives an example of the decisions taken around the pension system in Germany, which now exasperate him, whereas before, when he was visiting Europe for the first time, local problems seemed as distant as those in America or other continents. The process of putting down roots in Europe includes becoming involved, expending emotional energy and caring about the local matters.

A highly significant fact is, however, that the definition of Europe in Matt's case includes only the western part of the continent.

Of course when I say Europe I am always thinking West Europe ... and ... not, not even that East, Eastern Europe isn't in itself, it doesn't strike me as a remarkable thought but the one that's a trigger point of course for, I am uneasy about and, in the sense I don't know what to think of it exactly. ... When I say Europe I, my touchstone force is really, yeah, what I grew up with, which is Western Europe.

Matt's autobiographical narrative illustrates very well the processes by which Europe becomes biographically significant. It also shows how the meaning of Europe is constructed and reconstructed and how many ambiguities are involved. Being born in another continent as a descendant of Europeans sets a biographical task of dealing with one's background and 
working out one's own stance towards Europeanness. Critical reflection on one's heritage may lead both to a distancing and a deeper understanding of the complexities of belonging. In Matt's case, the fact that the concept of home became deterritorialised brings the need for additional biographical work. As home cannot be taken for granted anymore, it requires constant reflection and practical decisions concerning short-term arrangements and long-term roots. Narrating and thinking about his previous experiences, Matt does biographical work in order to understand what has been happening with him and to make his development understandable to his listener. Numerous argumentative segments suggest that there remain doubts and open questions in Matt's life and that more definite answers concerning his biographical identity, his search for home and his European belonging are still to be formulated. 